\title{
OPTIMALISASI PERKEMBANGAN REMAJA MELALUI TKT (TERAPI KELOMPOK TERAPEUTIK) DI KECAMATAN MEDAN AMPLAS DAN MEDAN JOHOR
}

\author{
1) Wardiyah Daulay, ${ }^{2)}$ Sri Eka Wahyuni, ${ }^{3)}$ Mahnum Lailan Nasution \\ ${ }^{1,2,3)}$ Program Studi S1 Keperawatan, Keperawatan, Universitas Sumatera Utara \\ ${ }^{1,2,3)}$ Jl. Prof. T. Maas No.3 Kampus USU Medan - Sumatera Utara - Indonesia \\ E-mail :wardiyah.daulay@usu.ac.id,eka_rizky06@yahoo.co.id,mahnum_lailan@yahoo.co.id
}

\begin{abstract}
ABSTRAK
Remaja adalah makhluk sosial yang sedang belajar keterampilan sosial. Tugas-tugas perkembangan pada masa remaja harus dioptimalkan agar tidak mudah mengalami gangguan pikiran, perasaan maupun perilaku. Stres, kesedihan, kecemasan, kesepian, keraguan pada diri remaja membuat mereka mengambil resiko dengan melakukan kenakalan. Kenakalan remaja yang ada di Kecamatan Medan Amplas dan Medan Johor sangat bervariasi. Berdasarkan wawancara dengan kepala lingkungan IX Medan Amplas dan kepala lingkungan XIII Medan Johor, bentuk kenakalan remaja mulai dari yang ringan seperti terlambat, membolos, merokok, menyontek sampai yang tindak kriminal seperti mencuri, perkelahian dan membully teman. Untuk menangani masalah perkembangan yang dihadapi remaja diperlukan pendekatan terapi kelompok terapeutik. Terapi kelompok terapeutik merupakan pilihan ideal dan penting bagi kelompok umur ini. Mereka menjadi mampu belajar antar satu sama lain sesuai perkembangan mereka, dapat membantu remaja dalam memenuhi kebutuhannya secara positif, bermakna bagi kelompok sebaya dan pembentukan identitas diri.
\end{abstract}

Kata Kunci: Remaja, Terapi Kelompok Terapeutik.

\begin{abstract}
Teenagers are social creatures who are learning social skills. Developmental tasks in adolescence must be optimized so that they are not prone to disorders of thought, feeling and behavior. Stress, sadness, anxiety, loneliness, self-doubt in adolescents make them take risks by engaging in delinquency. Juvenile delinquency in Medan Amplas and Medan Johor Subdistricts varies greatly. Based on interviews with the head of the IX Medan Amplas neighborhood and the head of the XIII Medan Johor neighborhood, the forms of juvenile delinquency ranged from mild, such as being late, truant, smoking, cheating to criminal acts such as stealing, fighting and bullying friends. To deal with developmental problems faced by adolescents, a therapeutic group therapy approach is needed. Therapeutic group therapy is an ideal and important option for this age group. They become able to learn from each other according to their development, can help adolescents meet their needs in a positive, meaningful way for peer groups and the formation of self-identity.
\end{abstract}

Keyword: Teenagers, Therapeutic group therapy

\section{PENDAHULUAN}

Kelompok merupakan lingkungan yang alamiah bagi remaja. Kelompok dapat berperan penting dalam mempengaruhi hubungan antar anggotanya. Interaksi kelompok dapat memberi kesempatan perkembangan psikologis remaja seperti pembentukan hubungan sosial, keterampilan sosial, meningkatkan interaksi sosial, dan memahami diri dan orang lain. Kelompok adalah kumpulan individu yang memiliki hubungan satu dengan yang lainnya, saling ketergantungan dan mempunyai norma [1]. Sedangkan menurut [2] kelompok adalah dua atau lebih orang yang mengembangkan hubungan interaktif dan berbagi tujuan atau masalah.

Ada bermacam-macam kelompok salah satunya kelompok sebaya. Remaja keterikatannya sangat kuat dengan kelompok sebayanya. Potensi masalah dan sumber koping dapat berasal dari kelompok sebaya. Remaja adalah makhluk sosial yang sedang belajar ketrampilan sosial, mereka sering lebih mempercayai teman sebaya dibanding orang yang lebih dewasa. Identitas 
diri remaja dapat dibentuk dari cara dia memandang dan berespon terhadap orang lain dalam kelompok [3].

Masa remaja meliputi usia antara 11 hingga 20 tahun. Adapun [4] membagi masa remaja menjadi remaja awal (13 hingga 17 tahun) dan masa remaja akhir (17 tahun hingga 18 tahun). Masa remaja awal dan akhir dibedakan oleh Hurlock karena pada masa remaja akhir individu telah mencapai transisi perkembangan yang lebih mendekati masa dewasa. Transisi perkembangan pada masa remaja berarti sebagian perkembangan masa kanak-kanak masih dialami namun sebagian kematangan masa dewasa sudah dicapai.

Sejalan dengan perubahan-perubahan yang terjadi dalam diri remaja, mereka juga dihadapkan pada tugas-tugas yang berbeda dari tugas pada masa kanak-kanak. Sebagaimana diketahui, dalam setiap fase perkembangan, termasuk pada masa remaja, individu memiliki tugas-tugas perkembangan yang harus dipenuhi. Apabila individu mampu menyelesaikan tugas perkembangan dengan baik, maka akan tercapai kepuasan, dan kebahagian juga akan menentukan keberhasilan individu memenuhi tugas-tugas perkembangan pada fase berikutnya. Beberapa perubahan yang dialami remaja adalah perubahan fisik, psikis, dan sosial.

Tugas-tugas perkembangan pada masa remaja yang disertai oleh berkembangnya kapasitas intelektual, stres dan harapan-harapan baru yang dialami remaja membuat mereka mudah mengalami gangguan baik berupa gangguan pikiran, perasaan maupun gangguan perilaku. Stres, kesedihan, kecemasan, kesepian, keraguan pada diri remaja membuat mereka mengambil resiko dengan melakukan kenakalan.

Di Kecamatan Medan Amplas dan Medan Johor banyak remaja bermasalah. Berdasarkan wawancara dengan kepala lingkungan IX Medan Amplas dan kepala lingkungan XIII Medan Johor, bentuk kenakalan remaja mulai dari yang ringan seperti terlambat, membolos, merokok, menyontek sampai yang tindak kriminal seperti mencuri, perkelahian dan membully teman.

Selain itu ada juga yang mengalami masalah non kriminal. Jenis ini cenderung tertarik pada kesenangan-kesenangan yang sifatnya menyendiri, apatis terhadap kegiatan masyarakat atau sekolah. Remaja ini suka mengasingkan diri, menghindarkan diri dari kegiatan yang menumbuhkan kontak dengan orang lain. Perasaannya sangat peka dan mudah terluka, cepat tersinggung dan membesar-besarkan kekurangannya sendiri, dengan gejala umum sering menyendiri, melamun, apatis tidak bergairah, sangat mudah tersinggung, sangat mudah panik, dan bingung.

Untuk itu dalam upaya menangani masalah perkembangan yang dihadapi remaja pendekatan terapi kelompok sangat tepat dipilih [5]. Terapi kelompok terapeutik merupakan pilihan ideal dan penting bagi kelompok umur ini [6]. Mereka menjadi mampu belajar antar satu sama lain sesuai perkembangan mereka [7], dapat membantu remaja dalam memenuhi kebutuhannya secara positif, bermakna bagi kelompok sebaya dan pembentukan identitas diri $[1]$.

\section{METODE PELAKSANAAN}

Metode yang digunakan pada kegiatan pengabdian ini adalah metode wawancara untuk pengkajian, metode diskusi dan tanya jawab untuk stimulasi perkembangan. Dan metode dinamika kelompok untuk permainan dalam sesi. Terapi kelompok ini sesi-sesinya mengacu pada aspek perkembangan remaja menurut [8], [9] dan [10], yang terbagi menjadi tujuh sesi 
yaitu:

\section{Sesi Pertama}

Pengkajian dan diskusi perkembangan remaja. Pada sesi ini terapis mengkaji perkembangan masing-masing anggota yang telah dicapai dan bagaimana upaya memenuhi tugas perkembangannya yang meliputi 10 aspek perkembangan yaitu perkembangan biologi/fisik, psikoseksual, kognitif, psikososial, moral, spiritual, bahasa, emosi, kreativitas, dan bakat khusus. Selanjutnya memaparkan ciri-ciri, tugas perkembangan remaja yang sehat dan penyimpangan yang dapat terjadi.

\section{Sesi kedua:}

Stimulasi perkembangan biologis/fisik dan psikoseksual. Pada sesi ini anggota berdiskusi tentang stimulasi perkembangan biologi dan psikoseksual dan berbagi pengalaman stimulasi perkembangan yang pernah diperoleh dari lingkungan keluarga, sekolah, maupun masyarakat. Selanjutnya diskusi tentang cara menjaga kesehatan badan, kebiasaan hidup sehat dan bersih, olahraga secara teratur, cara mengontrol hasrat seksual dan akibatnya bila tidak dilakukan. Pada bagian akhir fase kerja anggota diminta membuat komitmen terhadap kesehatan fisik dan psikoseksual.

\section{Sesi ketiga:}

Stimulasi perkembangan kognitif dan bahasa. Pada sesi ini anggota berdiskusi tentang stimulasi perkembangan kognitif dan bahasa serta berbagi pengalaman stimulasi perkembangan yang pernah diperoleh dari lingkungan keluarga, sekolah, maupun masyarakat. Pada sesi ini dilakukan permainan "Tebak idolaku". Pada permainan ini setiap anggota di punggungnya di beri nama satu tokoh/selebritis terkenal. Selanjutnya mereka disuruh bertanya kepada anggota kelompok yang lain dengan maksimal tiga pertanyaan tertutup dengan jawaban ya/tidak. Waktu bertanya dibatasi selama 3 menit, setelah waktu habis mereka disuruh menebak siapa tokoh idola dibalik punggungnya. Kemudian mereka disuruh berpendapat terhadap tokoh tersebut, apa yang bisa dicontoh darinya. Selanjutnya mereka diminta membuat komitmen terhadap perkembangan kognitif dan bahasanya.

\section{Sesi keempat:}

Stimulasi perkembangan moral dan spiritual. Pada sesi ini anggota berdiskusi tentang stimulasi perkembangan moral dan spiritual dan berbagi pengalaman stimulasi perkembangan yang pernah diperoleh dari lingkungan keluarga, sekolah, maupun masyarakat. Pada sesi ini terapis melakukan permainan yang diberi nama "The best values" yang berisi tentang berbagai nilai-nilai pribadi dari yang paling penting - kurang penting, selanjutnya anggota di instruksikan untuk mengurutkan serta menyampaikan secara langsung alasannya. Terapis memberi kesempatan anggota lain saling memberikan pendapat. Pada bagian akhir fase kerja anggota diminta membuat komitmen terhadap perkembangan moral dan spiritual

\section{Sesi kelima:}

Stimulasi perkembangan emosi dan psikososial. Pada sesi ini anggota berdiskusi tentang stimulasi perkembangan emosi dan psikososial, selanjutnya mereka berbagi pengalaman 
stimulasi perkembangan yang pernah diperoleh dari lingkungan keluarga, sekolah, maupun masyarakat. Stimulasi dilakukan dengan menggunakan permainan dengan nama "Siapa Aku". Caranya masing-masing anggota kelompok diinstruksikan untuk menuliskan perasaannya sesuai pertanyaan yang telah disediakan. Selanjutnya membaca perasaannya disertai bahasa nonverbal didepan kelompok. kemudian masing-masing saling memberi tanggapan terhadap perasaan yang muncul. Pada bagian akhir fase kerja anggota diminta membuat komitmen perkembangan emosi dan psikososialnya.

\section{Sesi keenam:}

Stimulasi perkembangan bakat dan kreativitas. Pada sesi ini anggota berdiskusi tentang stimulasi perkembangan bakat dan kreativitas dengan berbagi pengalaman stimulasi perkembangan yang pernah diperoleh dari lingkungan keluarga, sekolah, maupun masyarakat. Pada sesi ini dilakukan kegiatan dengan nama "Unjuk Gigi" yaitu masing-masing anggota diinstruksikan menampilkan bakat dan kreativitasnya yang dimiliki selanjutnya anggota yang lain memberikan penghargaan. Pada bagian akhir fase kerja anggota diminta membuat komitmen untuk mengembangkan bakat dan kreativitasnya.

\section{Sesi ketujuh:}

Evaluasi manfaat dan stimulasi yang telah dilakukan. Pada sesi ini anggota berbagi pengalaman tentang manfaat kegiatan selama tujuh sesi, perubahan-perubahan apa yang telah dirasakan dan kegiatan positif apa yang telah dilakukan di rumah, sekolah, dan masyarakat. Selanjutnya anggota diberi tindak lanjut untuk mengeksplorasi semua potensi yang dimiliki, nilai-nilai, keyakinan dan membuat komitmen terhadap pilihan yang positif dan disenangi.

\section{HASIL}

\section{Kegiatan Persiapan}

Langkah awal pelaksanaan program pengabdian masyarakat dimulai dengan pengurusan surat tugas dari Lembaga Pengabdian kepada Masyarakat USU dan surat izin dari Fakultas Keperawatan USU. Setelah surat izin didapatkan maka tim pengusul menjumpai kepala lingkungan IX Kecamatan Medan Amplas dan Kepala Lingkungan XIII Medan Johor. Setelah mendapat izin, maka tim melakukan sosialisasi dengan kader dan mahasiswa yang akan dilibatkan tentang program kegiatan pengabdian masyarakat yang akan dilakukan. Kegiatan sosialisasi bertujuan untuk mendapatkan data/masukan dari kader terkait waktu dan tempat pelaksanaan pengabdian. Berdasarkan data yang dikumpulkan ternyata waktu luang remaja pada sore hari jam 16.00 sampai dengan jam 18.00 WIB dan tempat yang bisa dipakai adalah rumah kader dan mesjid.

\section{Kegiatan Pelaksanaan}

\section{Pelaksanaan sesi I TKT}

Kegiatan pengabdian masyarakat dilakukan dengan tahapan awal melakukan pengkajian dan diskusi perkembangan remaja. Kegiatan pada sesi ini meliputi :

- Terapis meminta anggota menyampaikan perkembangan dan permasalahan perkembangan yang dialami

- Terapis mendiskusikan ciri perkembangan yang sehat pada remaja 
- Terapis mendiskusikan penyimpangan perkembangan pada remaja

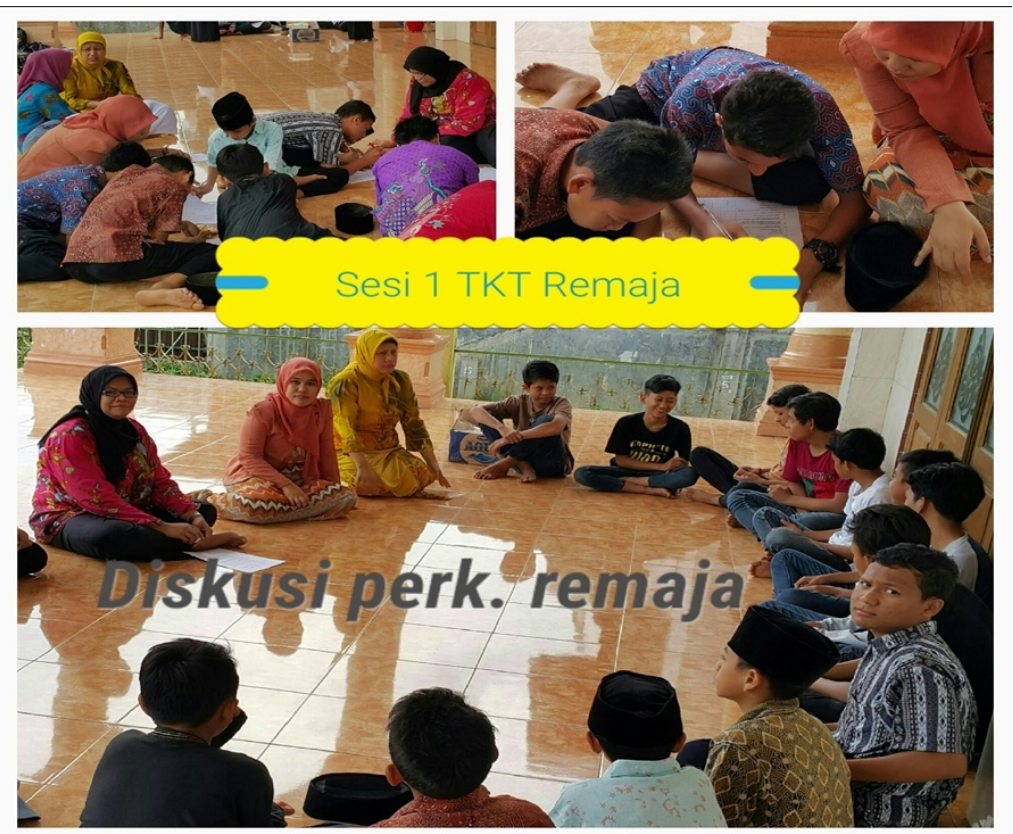

Gambar 1. Kegiatan Diskusi Perkembangan Remaja

\section{Pelaksanaan sesi II TKT}

Kegiatan pada sesi ini meliputi :

- Berdiskusi dan berbagi pengalaman tentang stimulasi perkembangan biologi dan psikoseksual yang pernah diperoleh dari keluarga, sekolah, maupun masyarakat.

- Diskusi tentang cara menjaga kesehatan badan, kebiasaan hidup sehat dan bersih, dan olahraga secara teratur,

- Diskusi cara mengontrol hasrat seksual dan akibatnya bila mengabaikan.

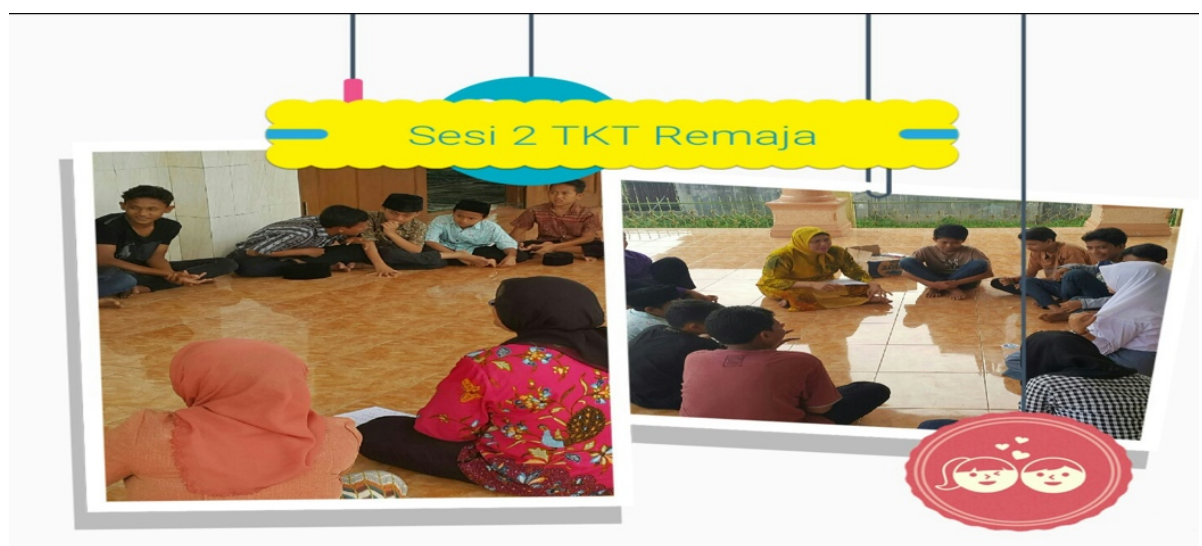

\section{Stimulasi biologis}

Gambar 2. Kegiatan Stimulasi Biologis Remaja 


\section{Pelaksanaan sesi III TKT}

Kegiatan pada sesi ini meliputi :

- Berdiskusi dan berbagi pengalaman tentang stimulasi perkembangan kognitif dan bahasa yang pernah diperoleh dari keluarga, sekolah, maupun masyarakat

- Permainan "Tebak idolaku". Caranya setiap anggota dikeningnya di beri nama satu tokoh/selebritis terkenal. Selanjutnya mereka disuruh bertanya kepada anggota kelompok yang lain dengan maksimal tiga pertanyaan tertutup dengan jawaban ya/tidak. Waktu bertanya dibatasi selama 5 menit, setelah waktu habis mereka disuruh menebak siapa tokoh idola di keningnya. Kemudian anggota berpendapat terhadap tokoh tersebut, apa yang bisa dicontoh darinya.

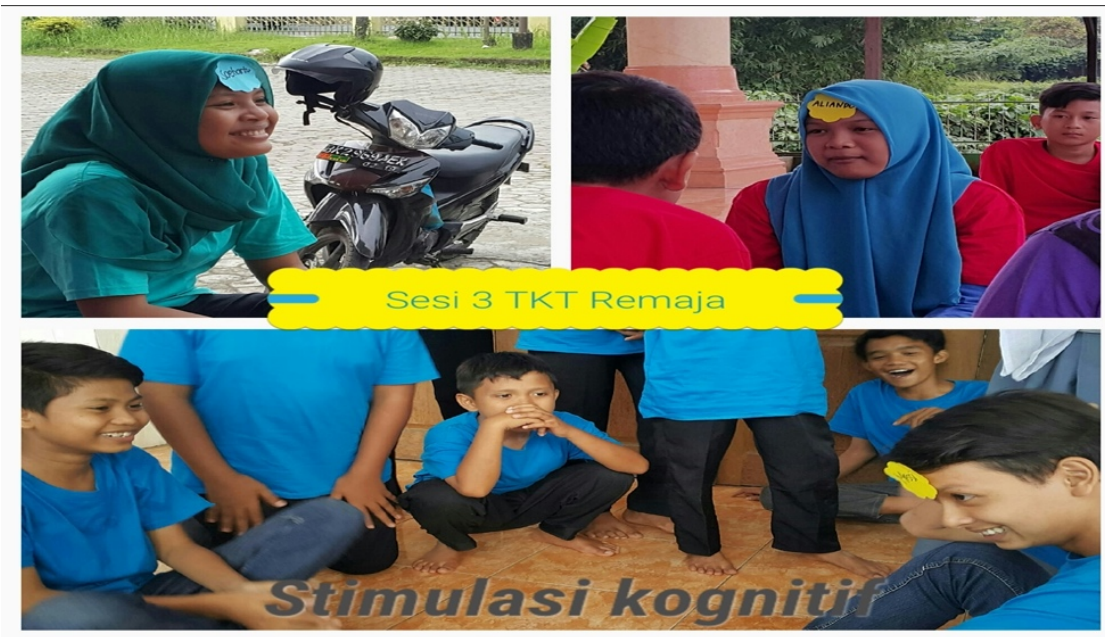

Gambar 3. Kegiatan Stimulasi Kognitif Remaja

\section{Pelaksanaan sesi IV TKT}

Kegiatan pada sesi ini meliputi :

- Berdiskusi dan berbagi pengalaman tentang stimulasi perkembangan moral dan spiritual yang pernah diperoleh dari keluarga, sekolah, maupun masyarakat.

- Permainan yang diberi nama "The Best Values" berisi tentang berbagai nilai-nilai pribadi dari yang paling penting - kurang penting, selanjutnya anggota di instruksikan untuk mengurutkan serta menyampaikan secara langsung alasannya. Terapis memberi kesempatan anggota lain saling memberikan pendapat.

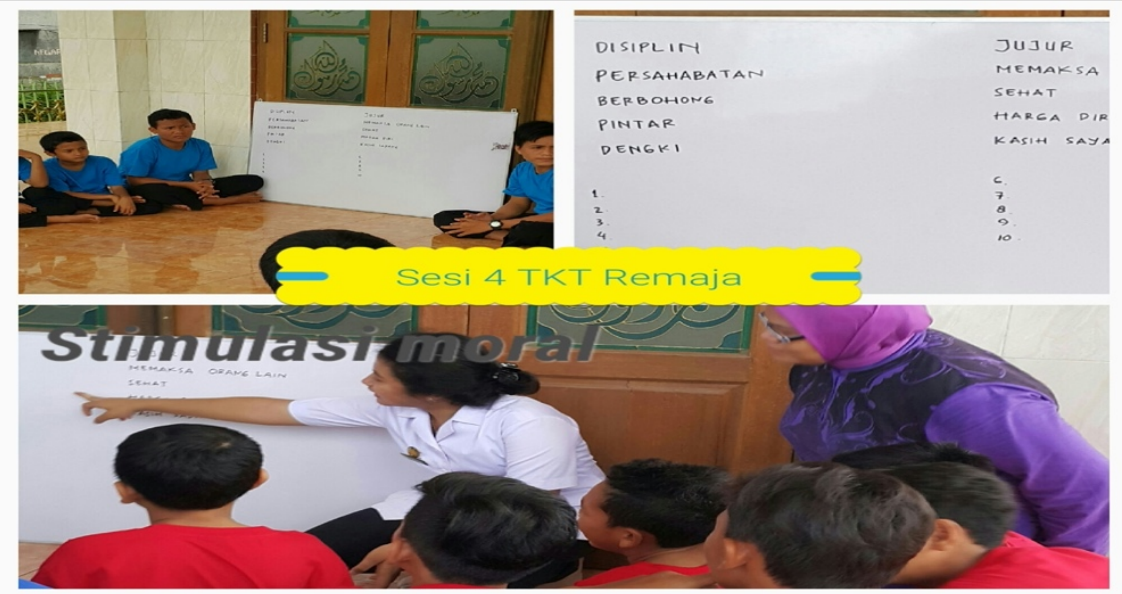

Gambar 4. Kegiatan Stimulasi Moral dan Spritual Remaja 


\section{Pelaksanaan sesi $V$ TKT}

Kegiatan pada sesi ini meliputi :

- Berdiskusi dan berbagi pengalaman tentang stimulasi perkembangan emosi dan psikososial yang pernah diperoleh dari keluarga, sekolah, maupun masyarakat

- Permainan dengan nama "Siapa Aku". Caranya masing-masing anggota kelompok diinstruksikan untuk menuliskan perasaannya sesuai pertanyaan yang telah disediakan. Selanjutnya membaca perasaannya disertai bahasa nonverbal didepan kelompok [11]. kemudian masing-masing saling memberi tanggapan terhadap perasaan yang muncul. Kemudian dari hasil pengamatan terhadap diri anggota diinstruksikan menetapkan cita-cita yang akan diraih. Fase ini diakhiri dengan membuat komitmen terhadap pengendalian emosi, hubungan sosial dan cita-citanya.

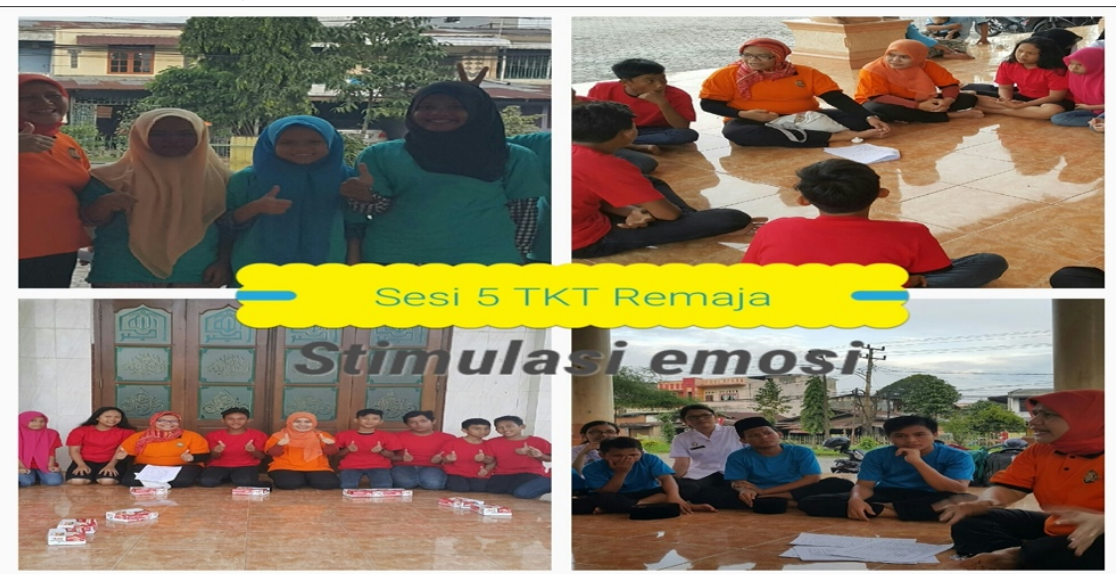

Gambar 5. Kegiatan Stimulasi Emosi dan Psikososial Remaja

\section{Pelaksanaan sesi VI TKT}

Kegiatan pada sesi ini meliputi :

- Berdiskusi dan berbagi pengalaman tentang stimulasi perkembangan bakat dan kreativitas yang pernah diperoleh dari keluarga, sekolah, maupun masyarakat

- Permainan dengan nama "Unjuk Gigi" yaitu masing-masing anggota diinstruksikan untuk menampilkan bakat dan kreativitasnya yang dimiliki. selanjutnya anggota yang lain saling memberikan penghargaan.

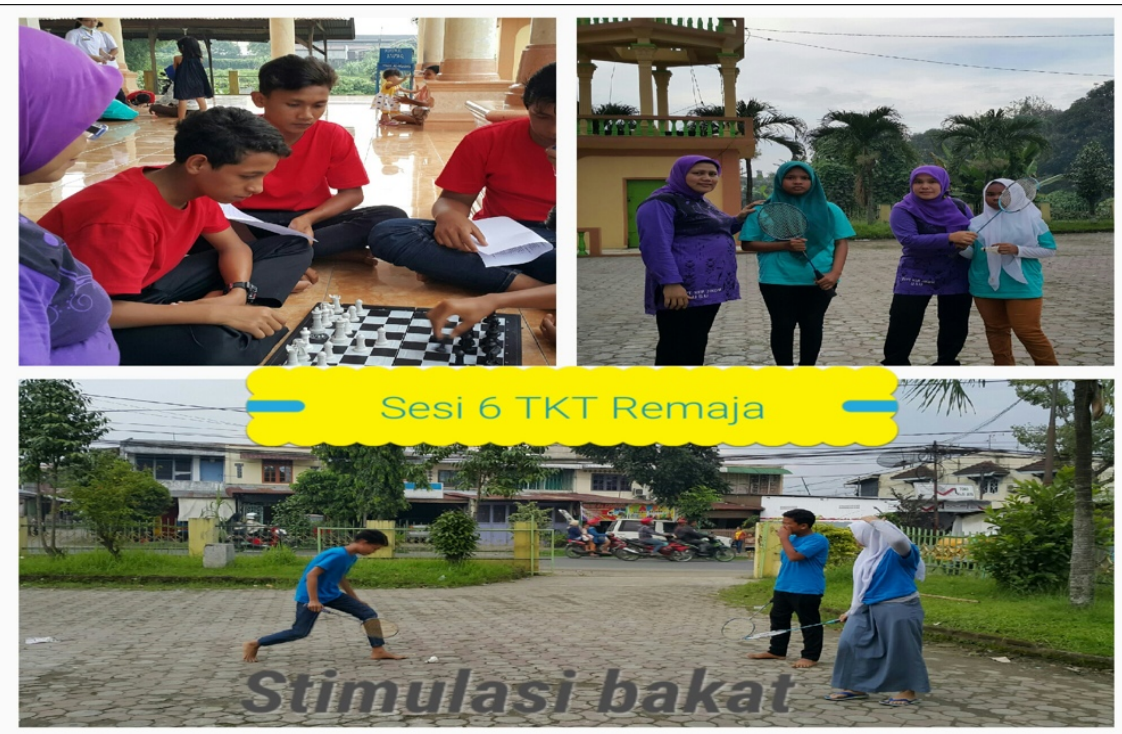

Gambar 6. Kegiatan Stimulasi Bakat dan Kreatifitas Remaja 


\section{Pelaksanaan sesi VII TKT}

Kegiatan pada sesi ini meliputi :

- Berbagi pengalaman tentang manfaat yang dirasakan selama kegiatan 6 sesi

- Menanyakan perubahan-perubahan yang terjadi setelah mengikut kegiatan

- Menanyakan upaya yang telah dilakukan di rumah, sekolah, dan masyarakat untuk meningkatkan perkembangannya

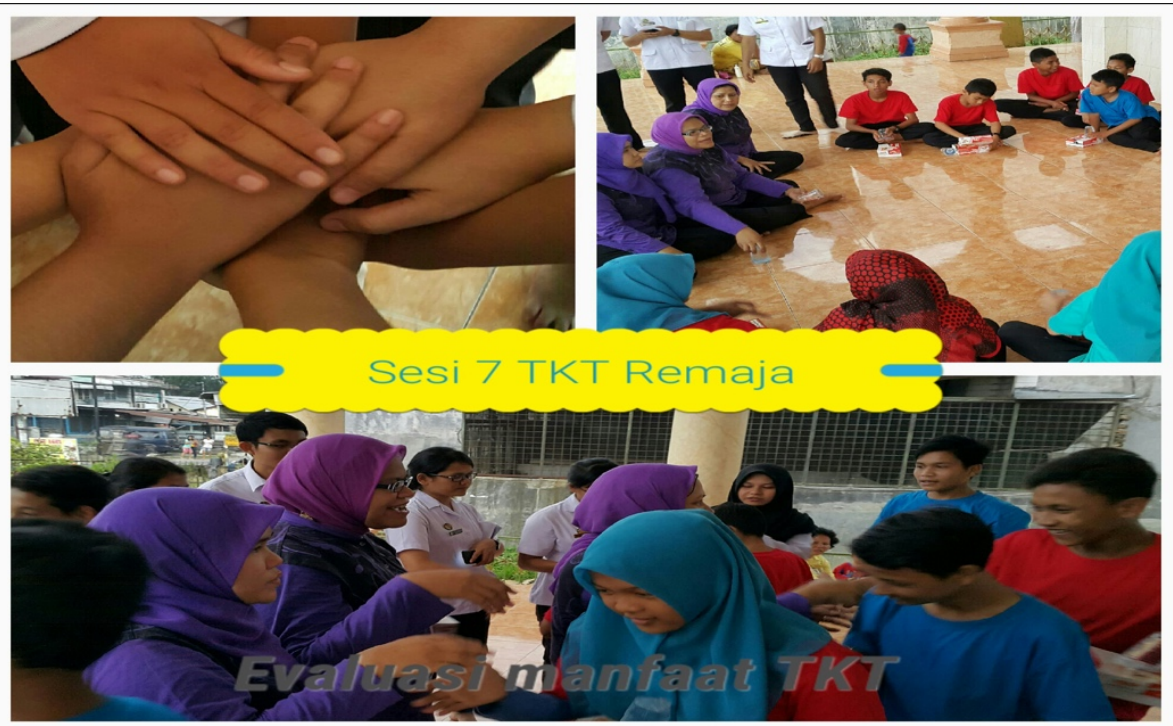

Gambar 6. Kegiatan Stimulasi Bakat dan Kreatifitas Remaja

\section{KESIMPULAN}

Berdasarkan tahapan kegiatan penagbdian masyarakat dapat disimpulkan bahwa remaja sangat antusias dan senang kegiatan ini dilakukan untuk mengisi banyaknya waktu luang yang mereka miliki. Remaja berharap kegiatan seperti ini dilakukan secara rutin sehingga mereka bisa saling berbagi, berdiskusi dan saling mendukung antar remaja di lingkungan masyarakat. Remaja berkomitmen bahwa kelompok yang sudah dibentuk akan tetap ada meskipun kegiatan pengabdian telah selesai, buku panduan pelaksanaan terapi kelompok terapeutik sangat berguna bagi kader dan orangtua. Dan melihat antusiasnya remaja melakukan kegiatan terapi kelompok terapeutik, maka diharapkan dukungan tokoh masyarakat dan petugas kesehatan untuk melakukan kegiatan seperti ini secara berkala.

\section{DAFTAR PUSTAKA}

[1] Stuart, G.W., \& Laraia M.T. "Principles and practice of psychiatric nursing”, ( $8^{\text {th }}$ ed), St. Louis: Mosby, 2005.

[2] Varcarolis E. M, Carson, V.B., \& Shoemaker, N.C. "Foundations of psychiatric mental health nursing", $5^{\text {th }}$ ed. St. Louis Missouri: Saunders Elsevier, 2006.

[3] Johnson, B.S., "Child, adolescence and family psychiatric nursing”. Philadelphia: J.B Lippincott Company, 1995

[4] Hurlock, E. B. Psikologi Perkembangan, Suatu Pendekatan Sepanjang Rentang Kehidupan (terjemahan). Jakarta: Erlangga, 2012.

[5] Fleitmen, M.(n.d.). “Group therapy for adolescents (ages 13-18)”. January 6, http://www.revitalizing psychiatry.com/contactUs.html, 2010. 
[6] Zelaskowski, P. (n.d). Adolescence and group psychotherapy. March 5, http://www.groupworks.info/writing/adolescence.htm, 2010.

[7] Wood, D. "Group therapy for adolescents": clinical paper. March 15, . http://www.mental-health-matters.com/index.php?option=com content\&view $=$ article\&id=99:group-therapy-for-adolescents-clinical-paper\&catid=43 :parenting\&Itemid=1652, 2009.

[8] Hockenberry, M., Wilson, D.,Winkelstein, M., \& Kline, N.“Nursing Care of infant and children", 7 ed. St. Louis, Missouri: Mosby Elsevier, 2003.

[9] Ali, M. dan Asrori, M. "Psikologi remaja perkembangan peserta didik”. Jakarta:PT Bumi Aksara , 2009.

[10]FIK. "Draft Terapi Kelompok Terapeutik". Depok: FIK-UI (tidak dipublikasikan), 2008.

[11]Santosa, V.E., dan Mulyani, I. M. "100 permainan kreatif untuk outbond \& training”.Yogyakarta: CV Andi offset, 2008. 